\title{
Pengembangan E-Book 3D Berbasis Aplikasi 3D Pageflip
}

\author{
Lastri Indriana*, Mukhlis Rohmadi
}

Program Studi Tadris Biologi, Jurusan Pendidikan Matematika dan Ilmu Pengetahuan Alam, Fakultas

Tarbiyah dan Ilmu Keguruan, IAIN Palangka Raya, Palangkaraya, Kalimantan Tengah, Indonesia

Email: lastriindriana99@gmail.com

\begin{abstract}
Abstrak
Penelitian ini bertolak dari belum tersedianya bahan ajar yang terintegrasi Keislaman dan berbasis $3 D$ PageFlip. Hasil analisis kebutuhan $100 \%$ peserta didik setuju jika e-Book $3 D$ berbasis aplikasi $3 D$ PageFlip materi sistem gerak terintegrasi Keislaman dikembangkan. Tujuan penelitian untuk mengembangkan deskripsi e-Book $3 D$ berbasis aplikasi $3 D$ PageFlip, mendeskripsikan kevalidan dan kepraktisan e-Book $3 D$ berbasis aplikasi $3 D$ PageFlip materi sistem gerak terintegrasi Keislaman kelas XI MA Darul Ulum Palangka Raya. Jenis penelitian ini adalah Research and Development (R\&D). Model pengembangan yang digunakan yaitu ADDIE (Analyze, Design, Development, Implementation, dan Evaluation Instrumen yang digunakan adalah angket analisis kebutuhan peserta didik, angket wawancara, angket validasi ahli materi, media dan integrasi Keislaman, angket respon peserta didik, dan angket keterlaksanaan pembelajaran. Data yang diperoleh dianalisis secara kuantitatif dan kualitatif dari setiap validator, peserta didik, dan observer. $E$-Book $3 D$ berbasis aplikasi $3 D$ PageFlip materi sistem gerak terintegrasi Keislaman diperoleh hasil yang valid oleh validator ahli materi, ahli media, dan ahli integrasi Keislaman. Kepraktisan e-Book $3 D$ berbasis aplikasi $3 D$ PageFlip materi sistem gerak terintegrasi Keislaman diperoleh hasil yang baik berdasarkan hasil respon peserta didik dan hasil observasi keterlaksanaan pembelajaran. Berdasarkan hasil validasi dan kepraktisan, maka $e$-Book $3 D$ berbasis aplikasi 3D PageFlip materi sistem gerak terintegrasi Keislaman layak untuk diujicobakan ke skala besar.
\end{abstract}

Kata Kunci : e-Book 3D, Sistem Gerak, Terintegrasi Keislaman

\section{Abstract}

This research stems from the unavailability of integrated Islamic teaching materials based on 3D PageFlip. The results of the analysis of needs $100 \%$ of students agreed that the 3D e-Book based on the PageFlip 3D application of Islamic integrated motion system material was developed. The research objective was to develop a description of the 3D e-Book based on the PageFlip 3D application, to describe the validity and practicality of the 3D e-Book based on the PageFlip 3D application of the integrated Islamic motion system for class XI MA Darul Ulum Palangka Raya. This type of research is Research and Development (R\&D). The development model used was ADDIE (Analyze, Design, Development, Implementation, and Evaluation). The instruments used were a student needs analysis questionnaire, interview questionnaire, material expert validation questionnaire, Islamic media and integration, student response questionnaires, and learning implementation questionnaires. The data obtained were analyzed quantitatively and qualitatively from each validator, student, and observer. 3D E-Book based on the 3D PageFlip application of Islamic integrated motion system material obtained valid results by material expert validators, media experts, and Islamic integration experts. -The 3D Book based on the 3D PageFlip application of Islamic integrated motion system material obtained good results based on the results of student responses and the results of observations of learning implementation Based on the results of validation and practicality, the 3D e-Book based on the 3D PageFlip application material for Islamic integrated motion systems is feasible to be tested down to scale big.

Keywords: 3D e-Book, Motion Systems, Islamic Integrated 
PENDAHULUAN

Menurut Mindayula
pemanfaatan dan penggunaan teknologi
informasi adalah cara yang bisa meningkatkan
kualitas hasil belajar peserta didik supaya
dapat belajar dengan efektif dan efisien.
Pemanfaatan media yang sesuai akan
berpengaruh terhadap kemudahan bagi peserta
didik dan guru untuk melangsungkan pembelajaran baik yang dilakukan dikelas atau pun mandiri. Pemanfaatan bahan ajar disesesuaikan dengan perkembangan zaman. Bahan ajar yang awalnya media cetak, perlu ditingkatkan kualitasnya menjadi sumber belajar yang pembelajarannya berbasis komputer atau e-Learning.

Penyampaian pesan atau informasi pembelajaran dapat diterima dengan baik oleh peserta didik dan tujuan pembelajaran akan tercapai jika seorang pendidik (guru) bisa menggunakan media pembelajaran. Azhar (2014) menyatakan media pembelajaran sebagai suatu perantara penyampaian pesan atau informasi dari sumber (guru) kepada penerima (peserta didik) supaya terjadi proses pembelajaran. Guru dapat menciptakan kegiatan belajar mengajar yang menyenangkan dan inovatif di dalam kelas dengan adanya media, sehingga dapat meningkatkan potensi serta aktivitas belajar peserta didik.

Salah satu media pembelajaran yang dapat diterapkan dalam proses pembelajaran yaitu 3D Pageflip Professional. 3D Pageflip Professional merupakan software aplikasi yang digunakan untuk membuat E-Book, Majalah digital, E-Paper dan lain-lain. 3D
Pageflip Professional merupakan jenis perangkat lunak profesi halaman flip untuk mengkonversi file PDF ke halaman-balik publikasi digital. Tiap halaman PDF yang di hasilkan bisa di flip (bolak-balik) seperti buku yang sesungguhnya. Dengan software $3 D$ Pageflip Professional dapat di tambahkan video, gambar, audio, hyperlink dan objek multimedia. Penggunaan software $3 D$ Pageflip Professional sangat mudah bagi siapa saja untuk membuat Flash $3 D$ yang realistis membalik halaman buku tanpa keterampilan pemrograman (Magdalena \& Novianti, 2018).

Kemajuan bangsa dapat diterapkan dengan bahan ajar yang terintegrasi keislaman melalui proses belajar di sekolah. Bahan ajar yang terintegrasi keislaman dilakukan dengan cara mengutip ayat Al-Qur'an dan hadits yang berhubungan dengan materi pembelajaran untuk menyisipkan nilai-nilai religius ke dalam pembelajaran. Proses belajar dengan mengintegrasikan nilai-nilai keislaman, bertujuan agar peserta didik dapat memahami bahwa ilmu pengetahuan bersumber pada Alquran dan hadits. Nilai-nilai keislaman di dalam program belajar yaitu terdapat pada aspek keimanan, ketaqwaan, akhlak mulia, cerdas dan mandiri (Sari, 2019).

Penelitian oleh Mulyono dkk (2016) tentang analisis kebutuhan buku ajar biologi Madrasah Aliyah (MA) terintegrasi keislaman di Kalimantan Tengah. Hasil penelitian menunjukkan bahwa belum tersedia buku ajar Biologi yang terintegrasi dengan keislaman. Hasil kuesioner menunjukkan tingkat kebutuhan yang tinggi terhadap buku mata 
pelajaran Biologi yang terintegrasi dengan keislaman. Belum tersedianya buku ini karena memang belum banyak penerbit yang menerbitkan buku pelajaran Biologi terintegrasi dengan keislaman.

Hasil wawancara pada guru yang mengajar Biologi kelas XI MA Darul Ulum Palangka Raya, data yang diperoleh yaitu pembelajaran yang berbasis multimedia belum pernah diterapkan. Bahan ajar yang digunakan hanyalah buku paket, belum ada bahan ajar yang berupa e-Book $3 D$ maupun yang terintegrasi Keislaman. Penggunaan teknologi sudah mulai berkembang disana, tetapi untuk peserta didik dalam pemanfaatan media handphone masih dibatasi. Handphone boleh dibawa ke kelas jika ada instruksi sebelumnya dari guru bersangkutan untuk keperluan proses pembelajaran di kelas. Guru Biologi kelas XI MA Darul Ulum menyampaikan akan sangat membantu dan mengapresiasi akan adanya bahan ajar terintegrasi Keislaman yang berbasis multimedia, khususnya e-Book $3 D$ karena akan lebih ringkas dibawa dan memudahkan proses pembelajaran yang materinya dianggap sulit, yaitu materi sistem gerak. Jumlah peserta didik kelas XI MA Darrul Ulum Palangka Raya adalah 29 orang dengan KKM 75.

Berdasarkan hasil analisis kebutuhan peserta didik, didapat bahwa peserta didik menganggap mata pelajaran bologi sulit untuk dipahami karena sulit untuk diingat dan banyak istilah asing, bahan ajar yang hanya dari buku, dan mereka belum pernah menggunakan bahan ajar berupa e-book $3 D$. Peserta didik menuliskan bahan ajar yang menarik sangat penting untuk menunjang proses pembelajaran. Peserta didik hanya melakukan aktivitas belajar disekolah dan jarang melakukan aktivitas belajar dirumah. Peserta didik $100 \%$ setuju dan merasa perlu adanya pengembangan e-Book $3 D$ materi sistem gerak yang terintegrasi keislaman sebagai bahan ajar dalam proses pembelajaran.

Alternative untuk mengatasi permasalahan yang didapat pada saat observasi adalah dengan mengembangkan bahan ajar yang menarik bagi peserta didik. bahan ajar salah satunya yang digunakan adalah e-book 3D. e-Book $3 D$ yang dikembangkan akan disertai dengan gambar-gambar dan video yang berkaitan dengan sistem gerak, serta memuat integrasi keislaman.

Pentingnya penelitian ini adalah untuk mengembangkan bahan ajar terintegrasi keislaman berupa e-Book $3 D$ yang menghasilkan media pembelajaran menggunakan software $3 D$ PageFlip yang valid dan untuk mengetahui respon peserta didik terhadap pengembangan media pembelajaran berbantuan software $3 D$ PageFlip melalui e-Book $3 D$ yang dikembangkan. Nilai-nilai keislaman yang diintegrasikan adalah dengan memadukan ilmu pengetahuan dan agama dengan tidak menghilangkan unsur-unsur dari kedua ilmu tersebut. Pengintegrasian keislaman melalui $e$ Book $3 D$ dengan materi sistem gerak disesuaikan dengan Kompetensi Dasar yang ada. Peneliti, melalui penelitian ini dapat memperoleh pengalaman dalam mengajar khususnya untuk penggunaan media pembelajaran serta dapat menjadi rujukan bagi 
pendidik untuk mengembangkan e-Book $3 D$ Terintegrasi keislaman. Melalui integrasi nilainilai keislaman ini diharapkan mampu meningkatkan pemahaman tentang ilmu biologi khususnya materi Sistem Gerak dan nilai-nilai keislaman yang ada didalamnya.

\section{METODE PENELITIAN}

Jenis penelitian yang digunakan dalam penelitian ini adalah pengembangan Research and Development (R\&D). Penelitian ini dimaksudkan untuk mengembangkan sumber belajar berbentuk $e$-Book $3 D$ berbasis aplikasi $3 D$ PageFlip materi sistem gerak terintegrasi keislaman kelas XI MA Darul Ulum Palangka Raya.

Subjek uji coba dalam penelitian ini adalah peserta didik kelas XI MA Darul Ulum Palangka Raya. Penentuan klasifikasi validasi oleh ahli media, ahli materi, ahli integrasi Keislaman, dan hasil respon peserta dan observer didasarkan pada rerata skor jawaban.

Kriteria validitas dapat dicari dengan rumus berikut:

$$
P=\frac{\Sigma X i}{\Sigma X} \times 100 \%
$$

Keterangan :

$\mathrm{P} \quad=$ Presentasi kelayakan

$\Sigma \mathrm{Xi}=$ Jumlah total skor jawaban validator (nilai nyata)

$\Sigma \mathrm{X}=$ Jumlah skor ideal

Tabel 1. Kriteria validasi

\begin{tabular}{cc}
\hline Persentasi (\%) & $\begin{array}{c}\text { Tingkat } \\
\text { Kevalidan }\end{array}$ \\
\hline $76-100$ & Valid \\
$51-75$ & Cukup valid \\
$26-50$ & Kurang valid \\
$0-25$ & Tidak valid \\
\hline
\end{tabular}

(Arikunto, 2010)
Selanjutya untuk melihat kepraktisan melalui respon peserta didik dan observasi keterlaksanaan pembelajaran melalui rumus berikut.

$$
\bar{x}_{\text {国 }}=\frac{\Sigma x}{n}
$$

Keterangan:

$$
\begin{array}{ll}
\left(\bar{x}_{\text {[] }}\right) & =\text { Skor rata-rata } \\
(\Sigma \mathrm{x}) & =\text { Jumlah skor } \\
(\mathrm{n}) & =\text { Jumlah butir }
\end{array}
$$

Tabel 2. Keterlaksanaan Pembelajaran

\begin{tabular}{cc}
\hline Interval & Kriteria \\
\hline $81-100$ & Sangat Berhasil \\
$61-80$ & Berhasil \\
$41-60$ & Cukup Berhasil \\
$21-40$ & Kurang Berhasil \\
$0-20$ & Tidak Berhasil \\
& \\
$P=\frac{\text { Skor Diperoleh }}{\text { Skor Tertinggi }} \times 100 \%$
\end{tabular}

Dengan interpretasi skor sebagai berikut:

Tabel 3. Kriteria Praktis

\begin{tabular}{cc}
\hline Skor & Kriteria \\
\hline $0-25$ & Tidak Baik \\
$26-50$ & Kurang Baik \\
$51-75$ & Cukup Baik \\
$76-100$ & Baik \\
\hline
\end{tabular}

\section{HASIL DAN PEMBAHASAN}

Pada penelitian pengembangan ini, menggunakan kerangka ADDIE yang terdiri dari 5 tahap, yaitu Analysis, Design, Develompent, Implementation, dan Evaluation. Namun, pada penelitian ini tahap implementation tidak dilakukan, karena uji produk hanya pada uji skala kecil.

\section{Analisis (Analysis)}

Pada tahap ini dapat diketahui dari wawancara dengan guru Biologi dan 
membagikan angket analisis kebutuhan kepada peserta didik. Berdasarkan data yang diperoleh dari angket analisis kebutuhan, peserta didik $100 \%$ setuju jika e-Book 3D pageFlip materi sistem gerak terintegrasi Keislaman dikembangkan di MA Darul Ulum Palangka Raya.

\section{Desain (Design)}

Pembuatan desain e-Book $3 D$ materi Sistem Gerak terintegrasi Keislaman adalah tahapan selanjutnya setelah dilakukan analisis kebutuhan. Unsur-unsur yang dicakup pada tahap ini meliputi penentuan struktur $e$-Book $3 D$ dan membuat instrumen penelitian yang divalidasi oleh ahli materi, ahli media, dan ahli integrasi Keislaman. Berikut adalah gambar sampul pada $e$-Book $3 D$ yang ditunjukan pada gambar di bawah ini.

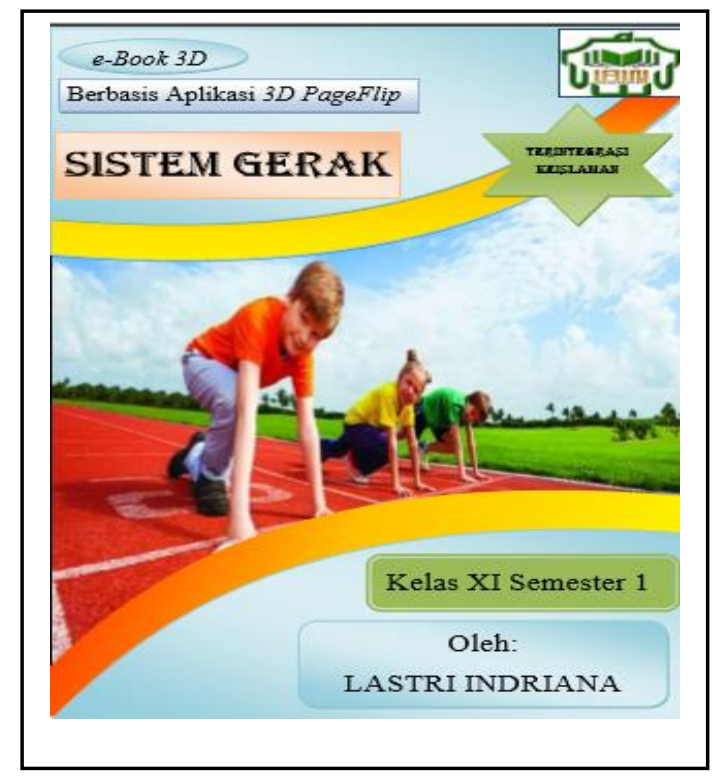

\section{Pengembangan (Development)}

E-Book $3 D$ dikembangkan dengan menggunakan aplikasi $3 D$ PageFlip Professional. Penulisan isi dan desain sampul e-Book 3D menggunakan aplikasi Ms. Office
Word. Produk e-Book 3D yang sudah selesai disusun akan divalidasi oleh ahli materi, ahli media, dan ahli integrasi Keislaman. Langkah selanjutnya setelah melakukan pengembangan adalah melakukan uji coba e-Book $3 D$ yang telah dikembangkan dan sudah di validasi oleh ahli. E-Book $3 D$ diujicobakan pada peserta didik kelas XI MA Darul Ulum Palangka Raya. Uji coba yang dilakukan hanya pada uji coba skala kecil.

\section{Evaluasi (Evaluation)}

Pada tahap evaluasi adalah tahap penilaian terhadap pengembangan e-Book $3 D$ yang telah dikembangkan. Penilaian meliputi validasi ahli materi, ahli media, dan ahli integrasi Keislaman.

Data hasil validasi dari beberapa ahli diperoleh hasil yang valid. Data dari angket respon dan observasi keterlaksanaan pembelajaran diperoleh hasil baik. Sehingga $e$ Book $3 D$ berbasis aplikasi $3 D$ pageFlip materi sistem gerak terintegrasi Keislaman layak untuk di lakukan uji coba.

\section{Analisis Data}

Data yang dianalisis adalah data hasil validasi dari ahli materi, ahli media, ahli integrasi Keislaman, angket respon peserta didik, dan angket observasi keterlaksanaan pembelajaran.

\section{Angket Validasi Materi}

Penentuan klasifikasi validasi oleh ahli materi didasaran pada rerata skor jawaban. Rerata skor diperoleh dengan cara jumlah skor dibagi jumlah butir. Berikut hasil data validasi oleh ahli materi. 
Tabel 3. Analisis Validasi Ahli Materi

\begin{tabular}{ccc}
\hline $\begin{array}{c}\text { Aspek } \\
\text { yang } \\
\text { dinilai }\end{array}$ & $\begin{array}{c}\text { Hasil Perolehan Skor } \\
\text { Validator } \\
\text { I }\end{array}$ & $\begin{array}{c}\text { Validator } \\
\text { II }\end{array}$ \\
\hline $\begin{array}{c}\text { Kelayakan } \\
\text { isi }\end{array}$ & 41 & 38 \\
$\begin{array}{c}\text { Kelayakan } \\
\text { penyajian }\end{array}$ & 48 & 42 \\
$\begin{array}{c}\text { Kelayakan } \\
\text { Bahasa }\end{array}$ & 28 & 27 \\
$\begin{array}{c}\text { Jumlah } \\
\text { Skor }\end{array}$ & 117 & 107 \\
$\begin{array}{c}\text { Presentase } \\
\text { Rata-Rata } \\
\text { Kriteria }\end{array}$ & $83 \%$ & $76 \%$ \\
\hline & & $80 \%$ \\
Valid \\
\hline
\end{tabular}

Berdasarkan data di atas diketahui validasi $e$-Book $3 D$ berbasis aplikasi $3 D$ PageFlip materi sistem gerak terintegrasi Keislaman untuk validasi ahli materi diperoleh rata-rata presentase $80 \%$ dengan kategori valid.

\section{Angket Validasi Media}

Penentuan klasifikasi validasi oleh ahli media didasaran pada rerata skor jawaban. Rerata skor diperoleh dengan cara jumlah skor dibagi jumlah butir. Berikut hasil data validasi oleh ahli media.

Tabel 4. Data hasil validasi ahli media

\begin{tabular}{ccc}
\hline $\begin{array}{c}\text { Aspek } \\
\text { yang } \\
\text { dinilai }\end{array}$ & $\begin{array}{c}\text { Hasil Perolehan Skor } \\
\text { Validator } \\
\text { I }\end{array}$ & $\begin{array}{c}\text { Validator } \\
\text { II }\end{array}$ \\
\hline $\begin{array}{c}\text { Ukuran } e- \\
\text { Book 3D }\end{array}$ & 6 & 6 \\
$\begin{array}{c}\text { Desain } \\
\text { Sampul }\end{array}$ & 34 & 35 \\
$\begin{array}{c}\text { Desain isi } \\
e-\text { Book }\end{array}$ & 54 & 55 \\
3D & \multicolumn{2}{c}{96} \\
$\begin{array}{c}\text { Jumlah } \\
\text { Skor }\end{array}$ & 94 & $96 \%$ \\
$\begin{array}{c}\text { Presentase } \\
\text { Rata-Rata } \\
\text { Kriteria }\end{array}$ & $75 \%$ & \multicolumn{2}{c}{$76,6 \%$} \\
& \multicolumn{3}{c}{ Valid } \\
\hline
\end{tabular}

Berdasarkan data hasil validasi ahli media diperoleh rata-rata presentase $76,6 \%$ dengan kategori valid.

\section{Angket Validasi Integrasi Keislaman}

Penentuan klasifikasi validasi oleh ahli materi didasaran pada rerata skor jawaban. Rerata skor diperoleh dengan cara jumlah skor dibagi jumlah butir. Berikut hasil data validasi oleh ahli materi.

Tabel 5. Data hasil validasi ahli integrasi Keislaman

\begin{tabular}{|c|c|c|}
\hline \multirow{2}{*}{$\begin{array}{c}\text { Aspek yang } \\
\text { dinilai }\end{array}$} & \multicolumn{2}{|c|}{ Hasil Perolehan Skor } \\
\hline & $\begin{array}{c}\text { Validator } \\
\text { I }\end{array}$ & $\begin{array}{c}\text { Validator } \\
\text { II }\end{array}$ \\
\hline $\begin{array}{c}\text { Keterpaduan } \\
\text { Integrasi } \\
\text { Keislaman }\end{array}$ & 20 & 17 \\
\hline Jumlah Skor & 20 & 17 \\
\hline Presentase & $100 \%$ & $85 \%$ \\
\hline Rata-Rata & \multicolumn{2}{|c|}{$92,5 \%$} \\
\hline Kriteria & \multicolumn{2}{|c|}{ Valid } \\
\hline
\end{tabular}

Berdasarkan data diatas validasi $e$-Book $3 D$ berbasis aplikasi $3 D$ PageFlip materi sistem gerak terintegrasi Keislaman untuk validasi ahli integrasi Keislaman diperoleh rata-rata presntase $92,5 \%$ dengan kriteria valid.

\section{Angket Observasi Keterlaksanaan Pembelajaran}

Observasi dilakukan selama kegiatan proses kegiatan pembelajaran berlangsung dan pengambilan data oleh masing-masing observer. Berikut data yang diperoleh dari observasi keterlaksanaan pembelajaran adalah. 
Tabel 6. Data hasil Observasi Keterlaksanaan pembelajaran

\begin{tabular}{|c|c|c|c|}
\hline \multirow[t]{2}{*}{ Penilaian } & \multicolumn{3}{|c|}{ Observer } \\
\hline & 1 & 2 & 3 \\
\hline Pendahuluan & 17 & 15 & 16 \\
\hline Kegiatan Inti & 34 & 36 & 33 \\
\hline Penutup & 19 & 20 & 17 \\
\hline Jumlah & 70 & 71 & 66 \\
\hline Rata-rata & 3.8 & 4 & 3,6 \\
\hline Rata-rata Seluruh & & 3,8 & \\
\hline Persentase & & $76 \%$ & \\
\hline Kriteria & & Berhasil & \\
\hline
\end{tabular}

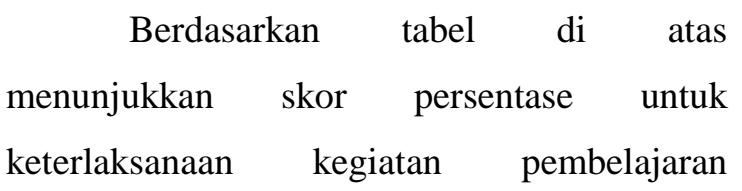

menggunakan $e$-Book $3 D$ berbasis aplikasi $3 D$ PageFlip materi Sistem Gerak terintegrasi Keislaman adalah 76\%. Maka, tingkat keterlaksanaan proses kegiatan pembelajaran menggunakan e-Book $3 D$ masuk dalam kategori "Berhasil".

\section{Angket Respon Peserta Didik}

Angket respon diserahkan kepada peserta didik setelah selesainya kegiatan pembelajaran. Hasil perolehan nilai untuk angket respon peserta didik dapat dilihat pada tabel 4.7 berikut.

Tabel 6. Hasil Respon peserta didik

\begin{tabular}{cccccc}
\hline No & Responden & Jumlah & Rata-rata & Presentase & Kriteria \\
\hline 1 & R1 & 60 & 4 & $100 \%$ & Sangat Baik \\
2 & R2 & 45 & 3 & $75 \%$ & Baik \\
3 & R3 & 46 & 3 & $76 \%$ & Baik \\
4 & R4 & 56 & 3,7 & $93 \%$ & Sangat Baik \\
5 & R5 & 57 & 3,8 & $95 \%$ & Sangat Baik \\
Rata Seluruh Peserta & \multicolumn{3}{c}{3,52} \\
Didik \\
Presentase Seluruh \\
Kriteria
\end{tabular}

yaitu: (1) sampul, (2) kata pengantar, (3)

Berdasarkan hasil angket respon peserta didik diketahui ada 5 tanggapan terhadap e-Book $3 D$ yang dikembangkan. Respon "Sangat Baik" diperoleh dari 3 peserta didik, sedangkan respon "Baik" diperoleh dari 2 orang peserta didik. Setelah di rata-ratakan maka diperoleh skor presentase seluruh peserta didik adalah $88 \%$ dengan kategori "Sangat Baik".

\section{SIMPULAN}

Berdasarkan hasil penelitian dapat ditarik kesimpulan sebagai berikut:

1. Deskripsi e-Book $3 D$ berbasis aplikasi $3 D$ PageFlip materi Sistem Gerak terintegrasi Keislaman kelas XI dengan deskripsi akhir petunjuk penggunaan e-Book $3 D$, (4) kompetensi inti dan kompetensi dasar, (5) daftar isi, (6) peta konsep, (7) pendahuluan, (8) kegiatan belajar (terdiri dari kegiatan belajar 1 dan 2), (9) rangkuman, (10) uji kompetensi, (11) refleksi, (12) umpan balik, (13) glosarium, (14) daftar pustaka, (15) kunci jawaban, (16) biodata penulis.

2. E-Book $3 D$ berbasis aplikasi $3 D$ PageFlip materi Sistem Gerak terintegrasi Keislaman kelas XI dinilai kevalidannya oleh ahli materi dengan kategori valid oleh validator I dan II dengan rata-rata skor persentase $80 \%$. Kevalidan $e$-Book $3 D$ dari validator I dan II ahli media yaitu dengan rata-rata skor persentase $76,6 \%$ dengan kriteria 
valid. Sedangkan dari validator I dan II ahli integrasi Keislaman diperoleh skor rata-rata 92,5\% dengan kategori valid.

3. E-book $3 D$ berbasis aplikasi $3 D$ PageFlip materi Sistem Gerak terintegrasi Keislaman dinilai kepraktisannya dari angket respon peserta didik diperoleh persentase keseluruhan adalah $88 \%$ dengan kategori Baik. Sedangkan analisis kepraktisan melalui angket keterlaksanaan pembelajaran dari observer diperoleh skor rata-rata persentase $76 \%$ dengan kategori berhasil.

\section{DAFTAR PUSTAKA}

Azhar, A. 2014. Media Pembelajaran. Jakarta: PT. Raja Grafindo.

Magdalena S, Novianti R. 2018. Pengembangan e-Book Konstektual Berbasis 3D PageFlip pada Materi Invertebrata untuk Siswa SMA Kelas X MIA. Jambi: Fakultas Keguruan dan Ilmu Pendidikan Universitas Jambi.

Mindayula E. 2017. Pengembangan Bahan Ajar e-Book Berbasis Metagonisi Menggunakan 3D PageFlip Materi Reaksi Redoks di Kelas X MIPA SMA Negeri 1 Muaro Jambi. Online. http://repository.unja.ac.id/id/eprint/15 16.

Rofi'i R, Mulyuno Y, Lestariningsih N, Ayatusa'adah A. 2016. Analisis Kebutuhan Buku Ajar Biologi Madrasah Aliyah (MA) Terintegrasi keislaman di Kalimantan Tengah. Discussion Paper. IAIN Palangka Raya.
Sari DIN. 2019. Internalisasi Nilai-Nilai Pendidikan Agama Islam di SMK Abdi Negara Tuban. Jurnal Studi Islam, 16(1): 45-61. 